\title{
Muscarinic receptors mediate stimulation of collagen synthesis in human lung fibroblasts
}

\author{
S. Haag*, S. Matthiesen*, U.R. Juergens ${ }^{\#}$ and K. Racké*
}

ABSTRACT: Clinical observations indicate that in chronic obstructive pulmonary disease patients, the long-acting muscarinic antagonist tiotropium delays decline in airway function, suggesting that cholinergic mechanisms contribute to long-term structural changes. Human lung fibroblasts express muscarinic receptors and the present study aimed to explore their role in controlling collagen synthesis.

MRC-5, HEL-299 and primary human lung fibroblasts (phLFb) were cultured. Incorporation of $\left[{ }^{3} \mathrm{H}\right]$-proline into cellular proteins was determined as measure of collagen synthesis.

In MRC-5 cells, the muscarinic agonist carbachol enhanced $\left[{ }^{3} \mathrm{H}\right]$-proline incorporation in a concentration-dependent manner (effective concentration of 50\%: $220 \mathrm{nM}$, increase at $10 \mu \mathrm{M}$ by

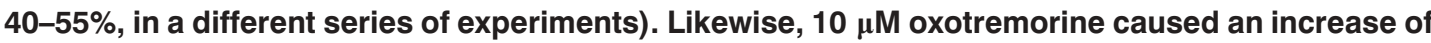
$\sim 65 \%$. For comparison, transforming growth factor- $\beta 1\left(5 \mathrm{ng} \cdot \mathrm{mL}^{-1}\right)$ caused an increase of $\sim 80 \%$. Effects of carbachol on total $\left[{ }^{3} \mathrm{H}\right]$-proline incorporation and collagenase-sensitive $\left[{ }^{3} \mathrm{H}\right]$-proline fraction were similar. The effect of $10 \mu \mathrm{M}$ carbachol was inhibited by tiotropium (inhibitory concentration of $50 \%: 110 \mathrm{pM}$ ), prevented by pertussis toxin and the mitogen-activated protein kinase inhibitor, PD 98059. Muscarinic agonists also enhanced $\left[{ }^{3} \mathrm{H}\right]$-proline incorporation in a tiotropium-sensitive manner in HEL-299 cells and phLFb.

In human lung fibroblasts, muscarinic receptors exert stimulatory effects on collagen synthesis. Prolonged blockade of muscarinic-induced collagen synthesis may contribute to reported beneficial long-term effects of anticholinergics in chronic obstructive pulmonary disease.

KEYWORDS: Airway remodelling, collagen synthesis, lung fibroblasts, mitogen-activated protein kinase, muscarinic receptors, tiotropium

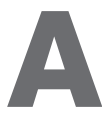

irway remodelling is a pathological feature observed in chronic inflammatory and obstructive airway diseases. Although airway remodelling processes in asthma and chronic obstructive pulmonary disease (COPD) are somewhat different, fibrotic alterations are observed in both diseases [1-3]. Based on their bronchodilatatory effects, anticholinergic drugs constitute an essential element in the therapy of obstructive airway diseases, particularly in COPD [4]. Moreover, preliminary clinical data indicate that, in patients with COPD, treatment with the longacting muscarinic antagonist tiotropium may delay the decline in airway function [5, 6], suggesting that cholinergic mechanisms may contribute to long-term structural changes, in addition to the well-known acute bronchoconstrictory and secretory effects $[7,8]$. Indeed, muscarinic agonists were found to enhance the proliferative response of human and bovine airway smooth muscle to growth factors [9, 10]. Moreover, in sensitised guinea pigs, tiotropium attenuated airway smoothmuscle mass thickening and prevented mucusgland hypertrophy induced by repeated allergen challenges [11, 12].

Since fibrotic alterations are crucial in airway remodelling [1-3], investigatons have recently begun into the expression and function of muscarinic receptors in pulmonary fibroblasts. The expression of different muscarinic receptors in primary human lung fibroblasts (phLFbs) and MRC-5 cells, a human fibroblast cell line derived from normal foetal lung tissue [13], has been revealed. In both cell types, $\mathrm{M}_{2}$ appeared to be the predominant receptor sub-type [14]. Moreover, in both cell types, muscarinic agonists induced a proliferative response [14, 15].

The present study aimed to further characterise the functional significance of muscarinic receptors
AFFILIATIONS

*Institute of Pharmacology and Toxicology, and

\#Dept of Pulmonary Diseases, Medical Polyclinic, University of Bonn, Bonn, Germany.

CORRESPONDENCE

K. Racké

Institute of Pharmacology and Toxicology University of Bonn Reuterstraße $2 b$ D-53113 Bonn Germany Fax: 49228735404 E-mail: racke.kurt@uni-bonn.de

Received:

October 022007

Accepted after revision: April 292008

STATEMENT OF INTEREST Statements of interest for K. Racké and the study itself can be found at www.erj.ersjournals.com/misc/ statements.shtml 
expressed in human pulmonary fibroblasts and investigated whether collagen synthesis is controlled by muscarinic mechanisms.

\section{MATERIALS AND METHODS Culture of lung fibroblasts}

MCR-5 human lung fibroblasts (CCL-171; American Type Culture Collection, Manassas, VA, USA) and HEL-299 fibroblasts (CCL-137; American Type Culture Collection) were grown in Eagle's minimal essential medium (MEM) supplemented with $10 \%$ foetal calf serum (FCS), $2 \mathrm{mM}$ L-glutamine, Earle's balanced buffered solution adjusted to contain $2.2 \mathrm{~g} \cdot \mathrm{L}^{-1}$ sodium bicarbonate, $0.1 \mathrm{mM}$ nonessential amino acids, $1.0 \mathrm{mM}$ sodium pyruvate, $100 \mathrm{U} \cdot \mathrm{mL}^{-1}$ penicillin and $100 \mu \mathrm{g} \cdot \mathrm{mL}^{-1}$ streptomycin. Cells were grown in a humidified incubator at $37^{\circ} \mathrm{C}$ and $5 \% \mathrm{CO}_{2}$ and passaged by trypsinisation at near confluence.

Normal areas of surgically resected lung tissue obtained from lung cancer patients after thoracotomy were used to establish
phLFbs. Anonymous lung tissue of male Caucasians was obtained from patients who gave informed consent. The protocol for obtaining human tissue was approved by the local ethical review board for human studies (Medical Faculty, University of Bonn, Bonn, Germany). Tissue was cut into small pieces, treated with pronase $\left(1 \mathrm{mg} \cdot \mathrm{mL}^{-1}\right.$; Calbiochem Novabiochem, San Diego, CA, USA) at $37^{\circ} \mathrm{C}$ for $30 \mathrm{~min}$, placed in cell culture plates and incubated in Eagle's MEM, supplemented as described previously [14] with FCS increased to 15\%. After 2 weeks, fibroblasts had grown from the tissue and were passaged by standard trypsinisation. In all experiments described in the present study, cells from passages 3-11 were used.

\section{Extraction of RNA and RT-PCR}

Total RNA was isolated using silica-gel-based membranes according to manufacturers' instructions but including an additional DNase digestion protocol in order to eliminate contamination by genomic DNA (Qiagen, Hilden, Germany). First strand cDNA was synthesised using Omniscript reverse
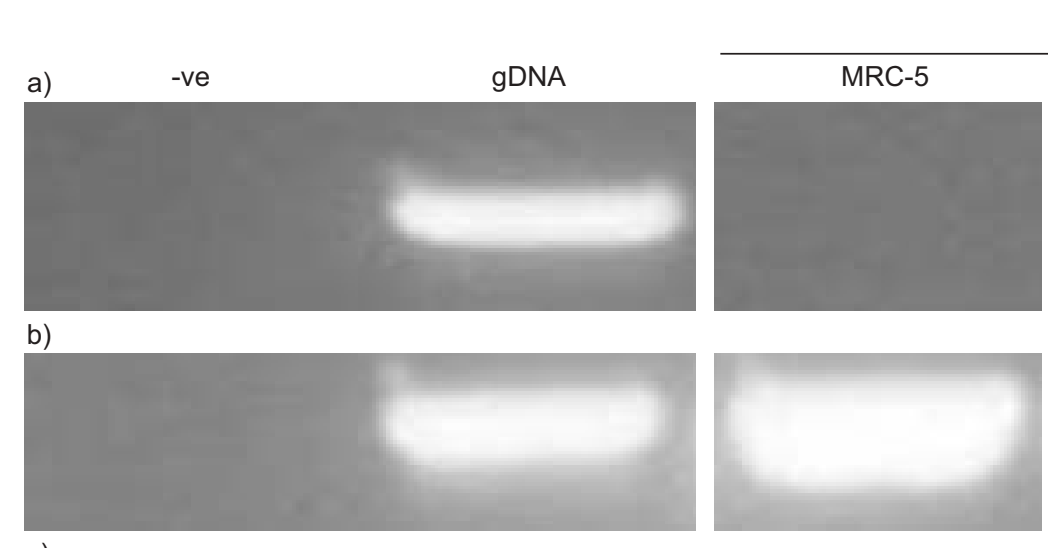

cDNA
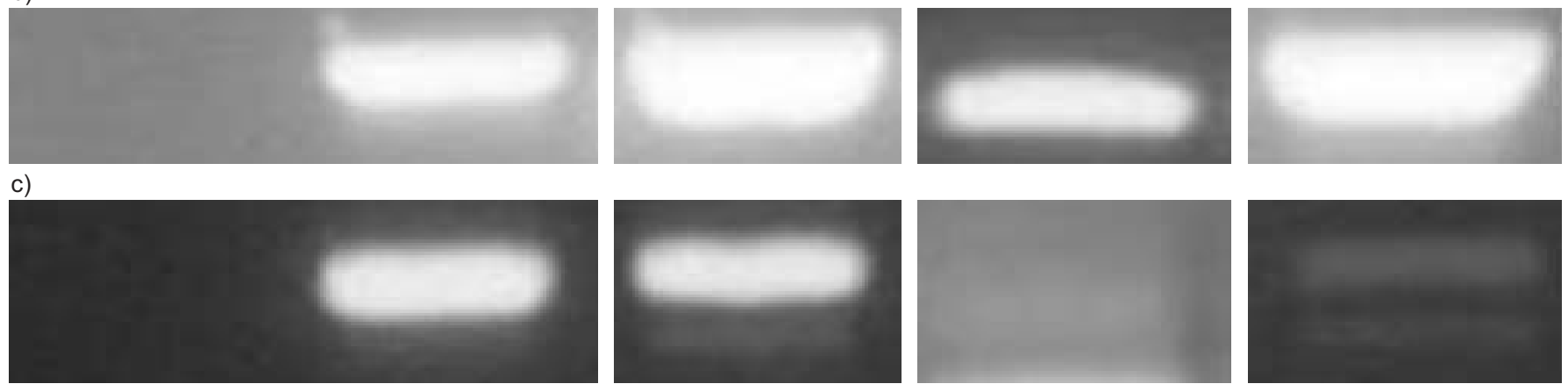

d)
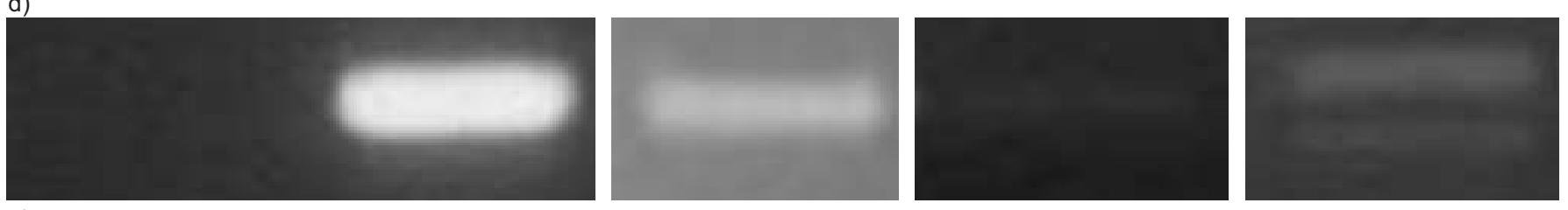

e)
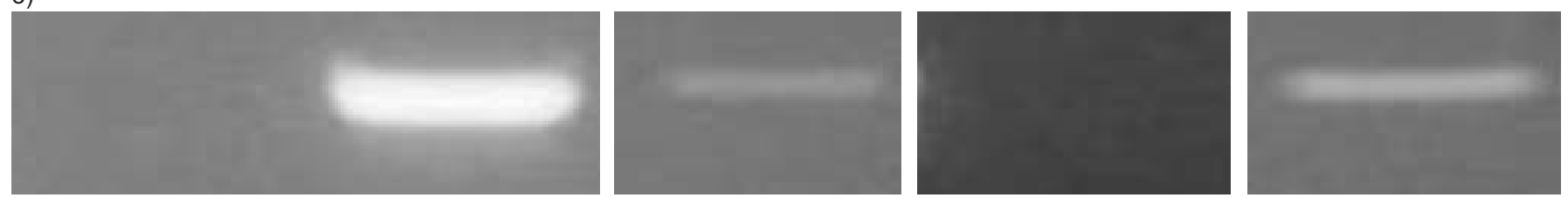

FIGURE 1. Samples of RT-PCRs of human muscarinic receptors on RNA isolated from different human lung fibroblasts, primary human lung fibroblasts (phLFb) and the cell lines MRC- 5 and HEL-299. a-e) Muscarinic receptor $M_{1}-M_{5}$, respectively. Cells were grown in 55 mm culture dishes to confluency, total RNA was isolated, treated with DNase and used for RT-PCR with primers specific for the human muscarinic receptors or $\beta$-actin. To control effectiveness of primer pairs, PCR was also performed on genomic DNA (gDNA) isolated from MRC-5 cells. One PCR lacking template DNA was performed regularly to exclude any contamination (-ve). PCR products were separated on a 1.2\% agarose gel. Each data set corresponds to observations from separate cell preparations (MRC-5 and HEL-299), or observations from cells obtained from an individual patient (phLFb). 

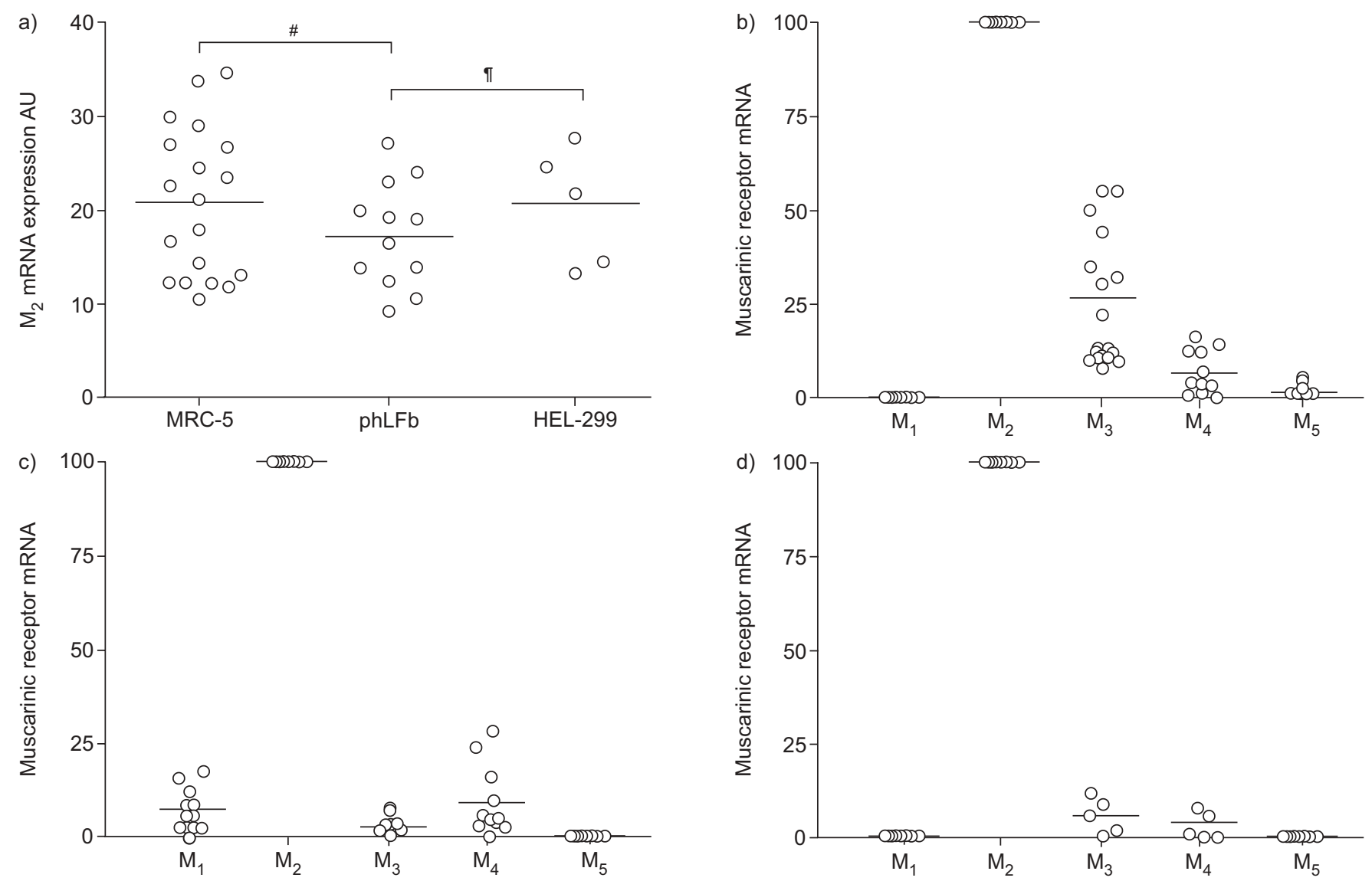

FIGURE 2. Densitometrical evaluation of a series of experiments. First, density values (arbitrary units; $A U$ ) were normalised over $\beta$-actin to correct for quality of the cDNA preparation and, secondly, over the respective amplification product obtained on gDNA to correct for effectiveness of the respective primer pair. a) Expression of mRNA encoding $M_{2}$ receptors in absolute terms. b-d) Expression of mRNA for $M_{1}-M_{5}$ receptors, expressed as percentage of the $M_{2}$ receptor value of b) MRC-5, c) phLFb and d) HEL-299. Individual observations and mean values (horizontal bar) are shown. ${ }^{*}: p=0.34 ;{ }^{\circ}: p=0.30$.

transcriptase (Qiagen). Specific oligonucleotide primers were constructed based on human EMBL sequences (The European Molecular Laboratory, Heidelberg, Germany): $\beta$-actin, 5'-CACTCTTCCAGCCTTCCTTC-3' and 5'-CTCGTCATACTCCTGCTTGC-3'; $\mathrm{M}_{1}$ receptor, 5'-CAGGCAACCTGCTGGTACTC-3' and 5'-CGTGCTCGGTTCTCTGTCTC-3'; $\mathrm{M}_{2}$ receptor, 5'-CTCCTCTAACAATAGCCTGG-3' and 5'-GGCTCCTTCTTGTCCTTCTT-3'; $\mathrm{M}_{3}$ receptor, 5'-GGACAGAGGCAGAGACAGAA-3' and 5'-GAAGGACAGAGGTAGAGTGG-3'; $\mathbf{M}_{4}$ receptor, 5' -ATCGCTATGAGACGGTGGAA-3' and 5'-GTTGGACAGGAACTGGATGA-3'; and $\mathrm{M}_{5}$ receptor, 5'-ACCACAATGCAACCACCGTC-3' and 5'-ACAGCGCAAGCAGGATCTGA-3'. PCR amplification was performed using Taq DNA polymerase in a programmable thermal cycler with initial heating for $3 \mathrm{~min}$ at $94^{\circ} \mathrm{C}$, followed by 23 and 35 cycles (for $\beta$-actin and $\mathrm{M}_{1}-\mathrm{M}_{5}$, respectively) of $45 \mathrm{~s}$ denaturation at $94^{\circ} \mathrm{C}$, annealing at $53-60^{\circ} \mathrm{C}(30 \mathrm{~s})$, extension at $72^{\circ} \mathrm{C}(1 \mathrm{~min})$ and final extension for $10 \mathrm{~min}$ at $72^{\circ} \mathrm{C}$. PCR products were separated using $1.2 \%$ agarose gel electrophoresis. Optical density of bands was quantified by RFLPscan version 2.01 software (MWG-biotech AG, Ebersberg, Germany), corrected over $\beta$-actin and referred to respective amplification of genomic DNA to normalise for variations in PCR effectiveness.

\section{$\left.{ }^{3} \mathrm{H}\right]$-proline incorporation}

Collagen synthesis and deposition into the extracellular matrix was assessed by $\left[{ }^{3} \mathrm{H}\right]$-proline incorporation assays originally developed by PETERKOFSKY and DiEgELMANN [16] and subsequently used in many studies [17-20]. Cells were trypsinised, harvested and seeded into 12-well dishes at a density of $10^{5}$ cells per well. Cells were first cultured for $24 \mathrm{~h}$ in the presence of $10 \%$ FCS, followed by an additional $24 \mathrm{~h}$ under FCS-free conditions. Following this, $\left[{ }^{3} \mathrm{H}\right]$-proline $(37 \mathrm{kBq})$ was added alone or in combination with the test drugs and the cells were cultured for a further $24 \mathrm{~h}$. After incubation, culture medium was removed and cells were washed twice with PBS at $4{ }^{\circ} \mathrm{C}$ followed by $1 \mathrm{~h}$ incubation in $1 \mathrm{~mL} \mathrm{20 \%}$ trichloric acid (TCA) at $4{ }^{\circ} \mathrm{C}$. Denaturated cells were scraped off, transferred into a reaction tube and centrifuged. The pellet was washed with $1 \mathrm{~mL} \mathrm{10 \%} \mathrm{TCA} \mathrm{and} \mathrm{dissolved} \mathrm{in} 300 \mu \mathrm{L} 0.2 \mathrm{M} \mathrm{NaOH}$ followed by neutralisation with $300 \mu \mathrm{L} 0.2 \mathrm{M} \mathrm{HCl}$. A scintillation cocktail (PerkinElmer, Jügesheim, Germany) was combined with $300-\mu \mathrm{L}$ portions of the pellet and radioactivity was determined by liquid scintillation spectrometry using a Packard 2100 TR liquid scintillation analyser (PerkinElmer). External standardisation was used to correct for counting efficiency. Three wells of each 12-well culture dish served as 

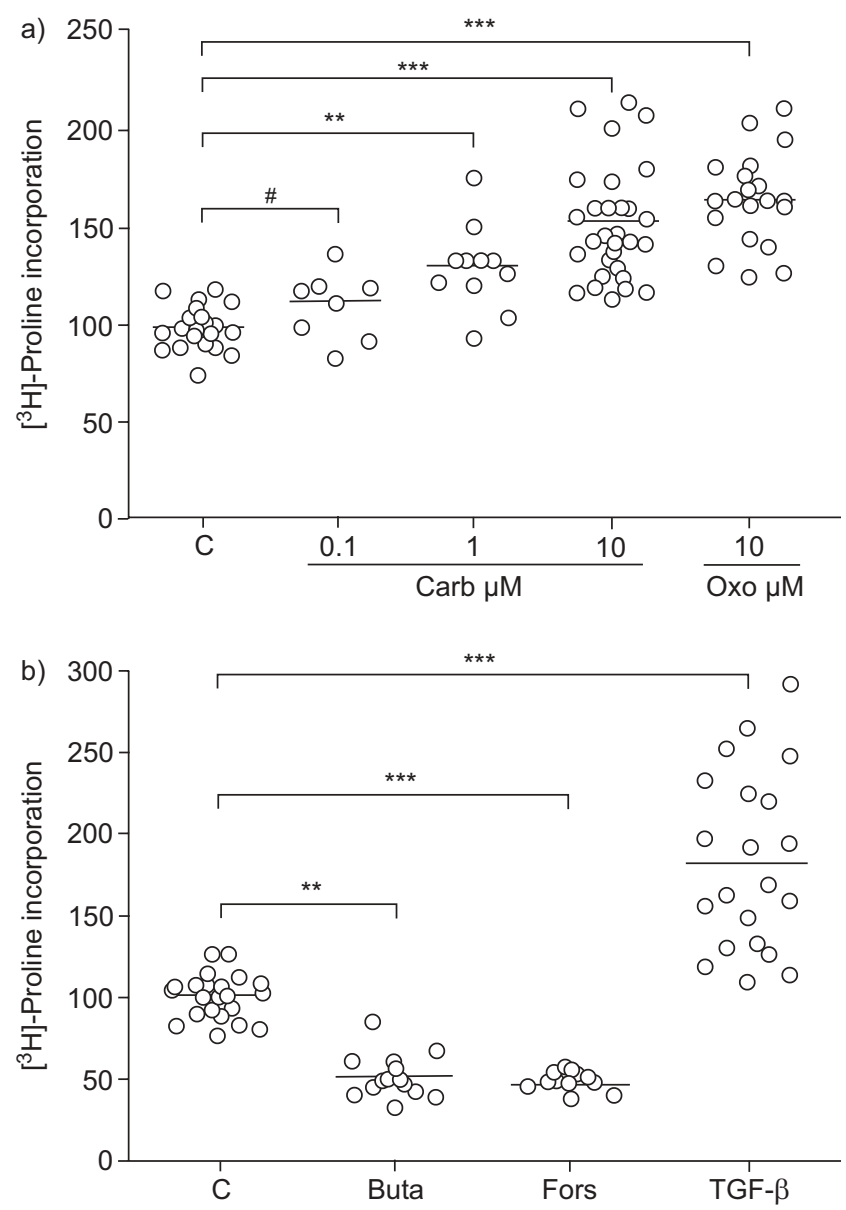

FIGURE 3. Effects of a) carbachol (Carb) and oxotremorine (Oxo), and b) butaprost (Buta), forskolin (Fors) and transforming growth factor (TGF)- $\beta_{1}$ on collagen synthesis in human lung fibroblasts (MRC-5 cells) as determined by $\left[{ }^{3} \mathrm{H}\right]$ proline incorporation. Incorporation of $\left[{ }^{3} \mathrm{H}\right]$-proline into cellular proteins is expressed as percentage of the mean value of the respective controls of each individual cell preparation. Individual observations and mean values (horizontal bar) are shown. C: control. ${ }^{*}: p=0.11 ;{ }^{*}: p<0.01 ; * * *: p<0.001$.

controls and data were expressed as percentage of the mean of these individual controls of each cell preparation. In addition, $\left[{ }^{3} \mathrm{H}\right]$-proline incorporation was also expressed in absolute terms (dpm).

In selected experiments, $100 \mu \mathrm{L}$ of collagenase II solution $\left(2 \mathrm{mg} \cdot \mathrm{mL}^{-1}\right.$ in buffer containing $50 \mathrm{mM}$ Tris-Base, $5 \mathrm{mM}$ EDTA, $20 \mathrm{mM} \mathrm{NaCl}$ and $5 \mathrm{mM} \mathrm{CaCl}_{2}$ ) was added to $300 \mu \mathrm{L}$ of neutralised protein extract followed by $1 \mathrm{~h}$ incubation at $37^{\circ} \mathrm{C}$. The digestion was terminated by addition of $100 \mu \mathrm{L} \mathrm{50 \%} \mathrm{TCA.}$ Samples were centrifuged at $18,000 \times g$ for $10 \mathrm{~min}$ and radioactivity in the supernatant (as a measure of collagenase-sensitive $\left[{ }^{3} \mathrm{H}\right]$-proline) was determined by liquid scintillation counting. Releasable radioactivity was expressed as percentage of the total incorporated radioactivity in each individual experiment.

\section{Statistical analysis}

Data are presented as scatter plots of the individual observations. In addition, mean \pm SEM values were calculated; these values are referred to when drug effects are described quantitatively in the text. Normal distribution was confirmed by performing the D'Agostino-Pearson omnibus normality test. Statistical significance of differences was evaluated by ANOVA followed by Dunnett or Bonferroni test. When normal distribution could not be confirmed (i.e. in all experimental series in which one treatment group had less than eight observations) significance of differences was evaluated by the Kruskal-Wallis test followed by Dunn's test. A p-value of $<0.05$ was considered as being significant. The inhibitory concentration of $50 \%\left(\mathrm{IC}_{50}\right)$ value was calculated.

\section{Drugs and materials}

Butaprost, carbachol (carbamylcholine chloride), nicotine bitatrate, oxotremorine sesquifumerate, PD-98059 (2-(2'-amino3'-methoxyphenyl)-oxanaphthalen-4-1), penicillin-streptomycin solution, pertussis toxin, transforming growth factor (TGF)- $\beta_{1}$ and trypsin were all purchased from Sigma (Deisenhofen, Germany); collagenase II was obtained from Cell Systems (St. Katharinen, Germany). Tiotropium bromide was a gift from Boehringer Ingelheim (Biberach, Germany). Eagle's MEM with Earl's salts and L-glutamine, and nonessential amino acids were obtained from PAA (Cölbe, Germany), FCS from Biochrom (Berlin, Germany), Taq DNA-polymerase from Invitrogen (Karlsruhe, Germany) and Omniscript reverse transcriptase, RNeasy Mini kit and RNase-free DNase set were all obtained from Qiagen. Oligodesoxynucleotides for RT-PCR were obtained from MWG-biotech.

\section{RESULTS}

Muscarinic receptor expression in human lung fibroblasts

In addition to the previously mentioned observations, abundant expression of $\mathrm{M}_{2}$ receptor mRNA was confirmed in a large number of observations in phLFbs and MRC-5 cells, as well as in HEL-299 cells, a further human lung fibroblast cell line [21] (figs 1 and 2). In all cells, mRNA encoding $M_{2}$ receptor was by far the most prominent muscarinic receptor transcript. The levels of $\mathrm{M}_{2}$ receptor mRNA appeared to be quite similar in phLFbs and the two other cell lines studied (fig. 2a). There were some differences with regard to the expression of other muscarinic receptor subtypes. $\mathrm{M}_{1}$ receptor transcript was only detected in primary cells whereas the levels of $\mathrm{M}_{3}$ transcripts were highest in MRC-5 cells followed by HEL-299 cells and primary cells (fig. $2 b-d$ ).

\section{Muscarinic stimulation of collagen synthesis in MRC-5 human lung fibroblasts}

Under control conditions, i.e. absence of FCS and any test drug, $\left[{ }^{3} \mathrm{H}\right]$-proline incorporation into cellular proteins amounted to $18,303 \pm 981 \mathrm{dpm}$ (84 individual observations under control conditions), since there was no significant difference between the different series of experiments, a pooled value is given. The muscarinic receptor agonist carbachol enhanced $\left[{ }^{3} \mathrm{H}\right]$-proline incorporation in a concentration-dependent manner, maximally by $\sim 55 \%$ at $10 \mu \mathrm{M}$ and with a half maximally effective concentration of $220 \mathrm{nM}$ (fig. 3a). Likewise, $10 \mu \mathrm{M}$ oxotremorine caused an increase of $\sim 65 \%$ (fig. 3a). In comparison, TGF- $\beta_{1}$, a well known activator of fibroblast collagen synthesis, caused an increase of $\sim 85 \%$, whereas the prostanoid $\mathrm{EP}_{2}$ receptor agonist butaprost $(100 \mathrm{nM})$ and forskolin $(10 \mu \mathrm{M})$, a direct activator of adenylyl cyclase, inhibited $\left[{ }^{3} \mathrm{H}\right]$-proline incorporation by $\sim 50 \%$ (fig. $3 \mathrm{~b}$ ). Following $1 \mathrm{~h}$ digestion by collagenase II, $\sim 80 \%$ of the 

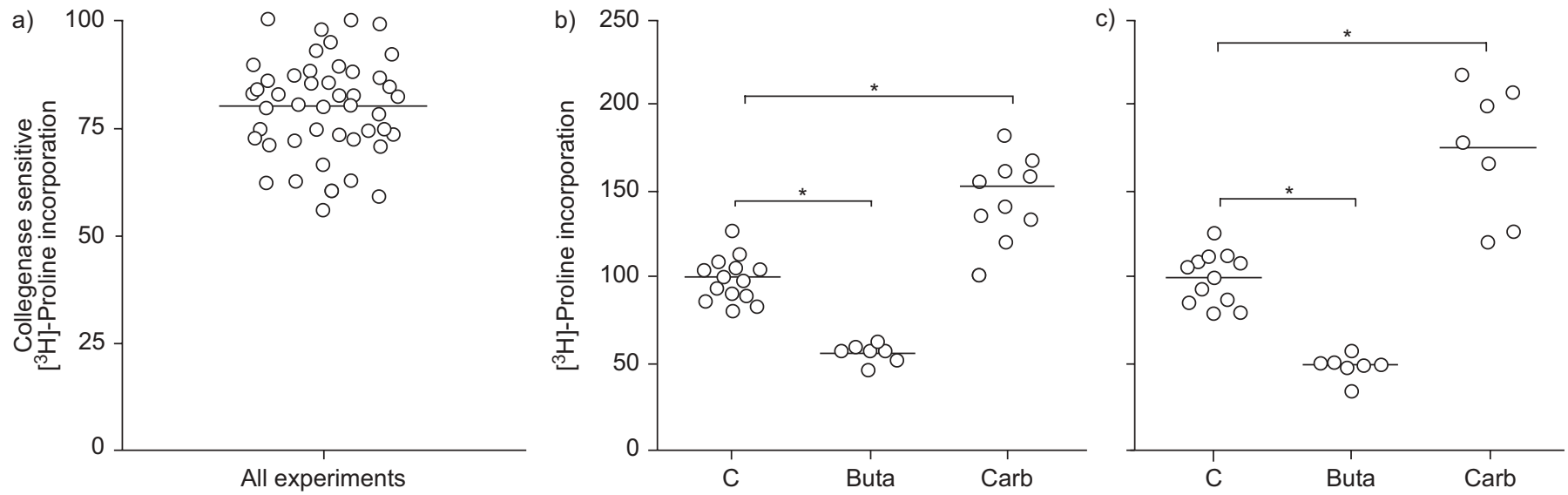

FIGURE 4. a) $\left[{ }^{3} \mathrm{H}\right]$-proline released by collagenase treatment, expressed as percentage of total protein $\left[{ }^{3} \mathrm{H}\right]$ in each individual experiment. Comparison of the effects of butaprost (Buta) and carbachol (Carb) on b) total and c) collagenase-sensitive $\left[{ }^{3} \mathrm{H}\right]$-proline incorporation into cellular proteins synthesised by human lung fibroblasts (MRC-5 cells) cultured as described in the Methods section. Cellular proteins were extracted and aliquots of the protein extracts were incubated for $1 \mathrm{~h}$ at $37^{\circ} \mathrm{C}$ in collagenase $\|$ $\left(2 \mathrm{mg} \cdot \mathrm{mL}^{-1}\right)$ containing buffer, and the releasable $\left[{ }^{3} \mathrm{H}\right]$-proline was determined. b and c) $\left[{ }^{3} \mathrm{H}\right]$-proline incorporation is expressed as percentage of the mean value of the respective controls of each individual cell preparation. Individual observations and mean values (horizontal bar) are shown. C: control. *: $p<0.05$.

$\left[{ }^{3} \mathrm{H}\right]$-proline was released from the protein fraction (fig. 4a), confirming that total $\left[{ }^{3} \mathrm{H}\right]$-proline incorporation largely reflects specific collagen synthesis. Furthermore, the effects of carbachol and butaprost on total $\left[{ }^{3} \mathrm{H}\right]$-proline incorporation were comparable to the effects on collagen-sensitive $\left[{ }^{3} \mathrm{H}\right]$-proline (fig. $4 \mathrm{~b}$ and c).

The stimulatory effect of $10 \mu \mathrm{M}$ carbachol on $\left[{ }^{3} \mathrm{H}\right]$-proline incorporation was inhibited in a concentration-dependent manner by the muscarinic receptor antagonist tiotropium with an $\mathrm{IC}_{50}$ of $110 \mathrm{pM}$ (fig. 5). Pre-treatment of the cells with pertussis toxin tended to decrease (by $\sim 20 \%$ ) basal $\left[{ }^{3} \mathrm{H}\right]$-proline

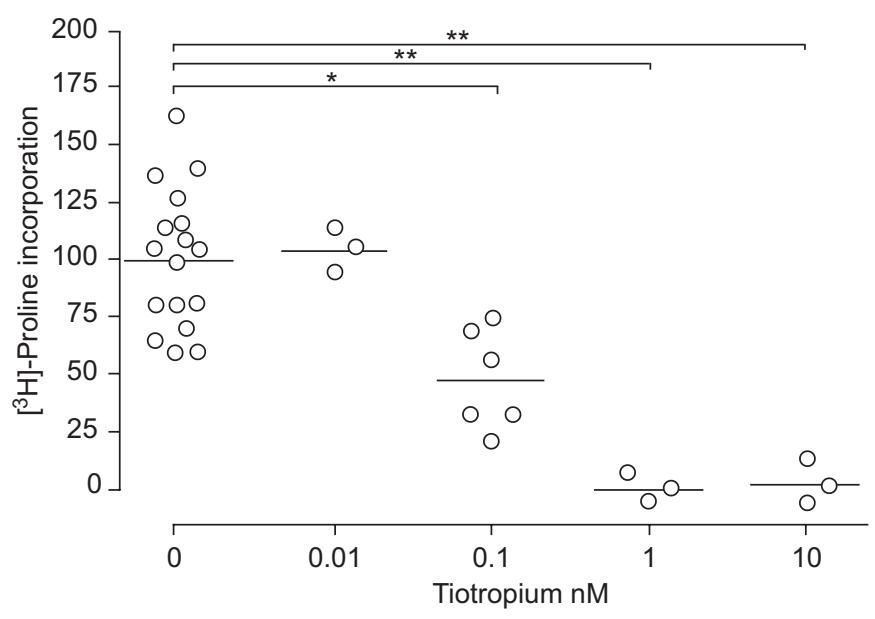

FIGURE 5. Concentration-dependent inhibitory effects of tiotropium on carbachol-induced stimulation of collagen synthesis by human lung fibroblasts (MRC-5 cells), as determined by $\left[{ }^{3} \mathrm{H}\right]$-proline incorporation. Cells were cultured as described in the Methods section. Each concentration of tiotropium was present 30 min prior to the addition of $\left[{ }^{3} \mathrm{H}\right]$-proline and carbachol. $\left[{ }^{3} \mathrm{H}\right]$-proline incorporation is expressed as percentage of the mean value of the respective carbachol-induced increase in the respective cell preparation. Individual observations and mean values (horizontal bar) are shown. The mean carbachol-induced increase in this series of experiments was $54 \pm 4 \%{ }^{*}: p<0.05 ;{ }^{* *}: p<0.01$ incorporation and prevented the stimulatory effect of $10 \mu \mathrm{M}$ carbachol (fig. 6a). Furthermore, PD 98059 (30 $\mu \mathrm{M})$, a specific inhibitor of the mitogen-activated protein kinase-activating enzymes [22] did not affect basal $\left[{ }^{3} \mathrm{H}\right]$-proline incorporation, but prevented the stimulatory effect of $10 \mu \mathrm{M}$ carbachol on $\left[{ }^{3} \mathrm{H}\right]$-proline incorporation (fig. 6b).

Nicotine failed to significantly affect $\left[{ }^{3} \mathrm{H}\right]$-proline incorporation. In the presence of 1,10 and $100 \mu \mathrm{M}$ nicotine, $\left[{ }^{3} \mathrm{H}\right]$-proline incorporation amounted to $103 \pm 9,119 \pm 6$ and $117 \pm 10 \%$, respectively, of controls (six observations from each).

\section{Muscarinic stimulation of collagen synthesis in HEL-299 and phLFbs}

In HEL-299 cells, basal $\left[{ }^{3} \mathrm{H}\right]$-proline incorporation $(14,915 \pm 557 \mathrm{dpm}, 18$ observations under control conditions) was not significantly different from that observed in MRC-5 cells, whereas in phLFbs, it was significantly lower compared with either cell line $(10,122 \pm 745 \mathrm{dpm} ; 42$ observations under control conditions; $\mathrm{p}<0.01)$. Nonetheless, in both cell types, muscarinic agonists stimulated $\left[{ }^{3} \mathrm{H}\right]$-proline incorporation (fig. 7) and the half maximally effective concentration for carbachol obtained in primary cells (165 nM) was comparable with that in MRC-5 cells. Finally, in both HEL-299 and the primary cells, the stimulatory effect of the muscarinic agonists $(10 \mu \mathrm{M}$ oxotremorine or $10 \mu \mathrm{M}$ carbachol) was blocked by $10 \mathrm{nM}$ tiotropium (fig. 7).

\section{DISCUSSION}

In human lung fibroblasts (primary cell and different cell lines), RNA encoding multiple muscarinic receptors was found to be transcribed. However, in all cells studied to date, $\mathrm{M}_{2}$ receptor mRNA was by far the most prominent transcript. In this regard, previous observations on phLFbs and MRC- 5 cells [14] were confirmed in the present study in a larger series of experiments and extended to HEL-299 cells (figs 1 and 2), another human lung fibroblast cell line [21]. In agreement with the current observations, two other recent studies demonstrated muscarinic receptor mRNA expression in phLFbs and 

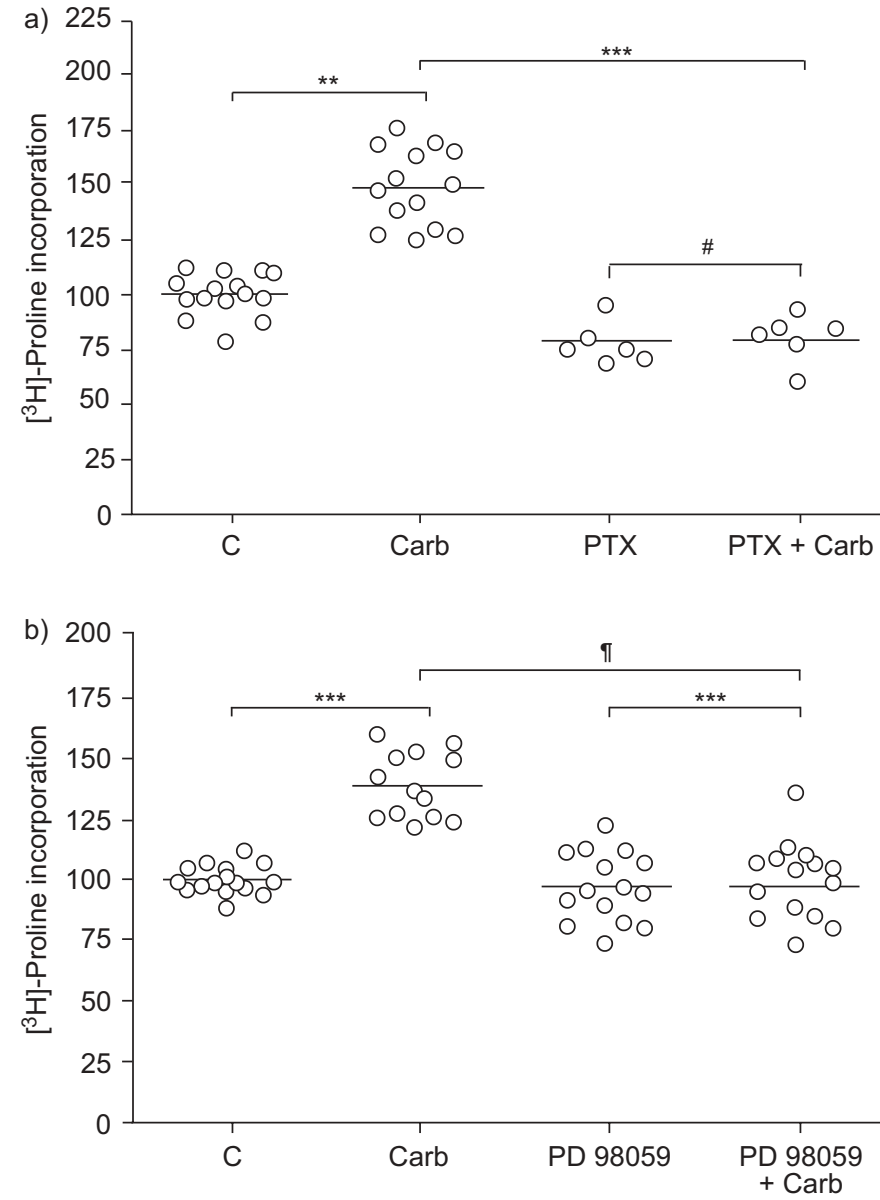

FIGURE 6. Effects of a) carbachol (Carb) and/or pertussis toxin (PTX), and b) Carb and/or PD 98059 on collagen synthesis by human lung fibroblasts (MRC-5 cells), as determined by $\left[{ }^{3} \mathrm{H}\right]$-proline incorporation. Cells were cultured as described in the Methods section. PTX $\left(0.1 \mu \mathrm{g} \cdot \mathrm{mL}^{-1}\right)$ was present $3 \mathrm{~h}$ and PD 9805930 min prior to the addition of $\left[{ }^{3} \mathrm{H}\right]$-proline and Carb $(10 \mu \mathrm{M})$. Incorporation of $\left[{ }^{3} \mathrm{H}\right]$-proline into cellular proteins was expressed as percentage of the mean value of the respective controls of each individual cell preparation. Individual observations and mean values (horizontal bar) are shown. C: control. ${ }^{*}: p=0.94$; ^: $p=0.96 .{ }^{* *}: p<0.01 ;{ }^{* *}: p<0.001$.

also observed a predominant expression of mRNA encoding the $\mathrm{M}_{2}$ subtype $[23,24]$.

In previous functional studies, it has been observed that muscarinic receptor activation can exert proliferative effects in both primary lung fibroblasts and MRC-5 cells [14, 15, 23]. The present study aimed to further explore the functional significance of muscarinic receptors in pulmonary fibroblasts and studied possible effects on collagen synthesis in MRC-5 and HEL-299 cells as well as in primary lung fibroblasts.

Collagens are proteins of particular high proline content and $\left[{ }^{3} \mathrm{H}\right]$-proline incorporation into newly synthesised proteins has often been used as a measure of collagen synthesis [16-20]. In the present study, digestion with collagenase confirmed that $\left[{ }^{3} \mathrm{H}\right]$-proline incorporation largely reflects collagen synthesis (fig. 4a) and that drug effects on total $\left[{ }^{3} \mathrm{H}\right]$-proline incorporation paralleled those on the collagenase-sensitive $\left[{ }^{3} \mathrm{H}\right]$-proline fraction (fig. $4 \mathrm{~b}$ and c). Moreover, stimuli known to inhibit
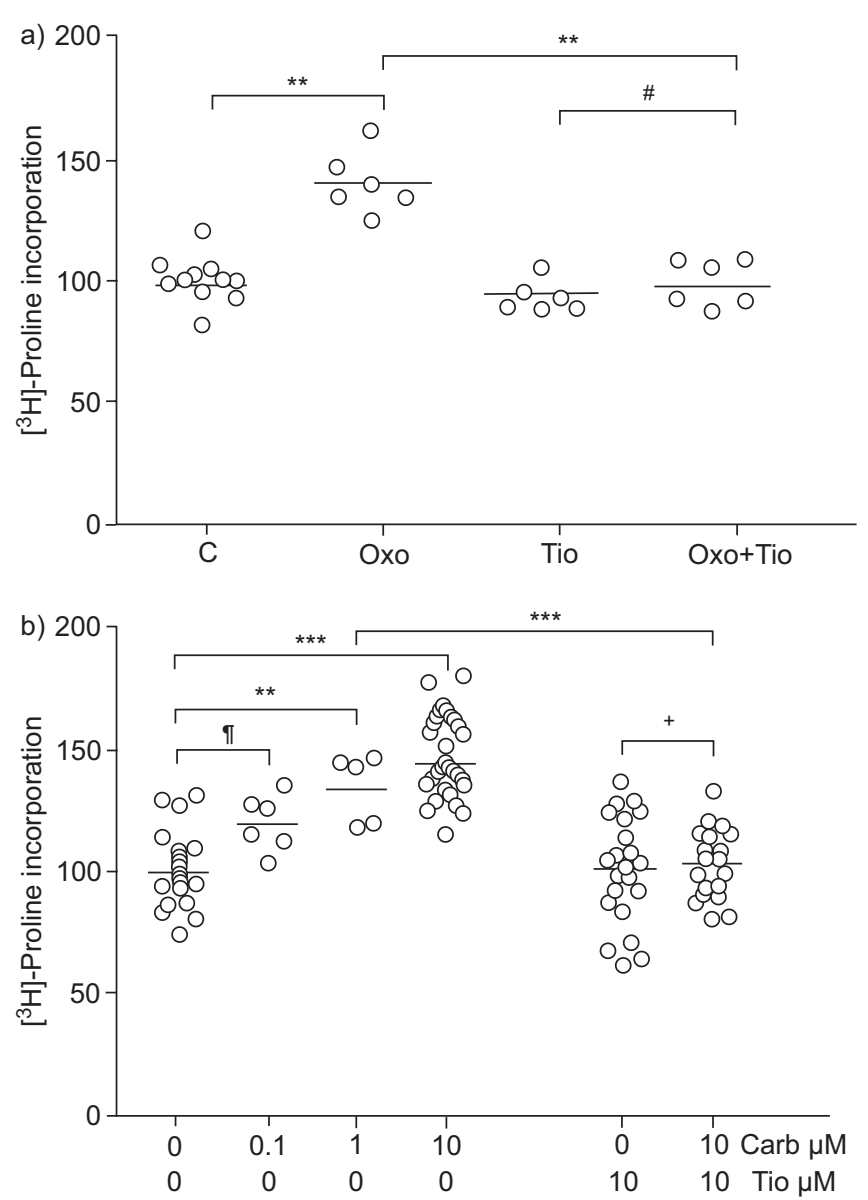

FIGURE 7. Effects of muscarinic agonists, in absence and presence of tiotropium, on collagen synthesis by a) HEL-299 and b) primary human lung fibroblasts as determined by $\left[{ }^{3} \mathrm{H}\right]$-proline incorporation. Primary cells were obtained from lung tissue of four patients and cells from each patient were used in different passages (3-11) for experiments. Cells were cultured as described in the Methods section. Tiotropium (Tio; $10 \mathrm{nM}$ ) was present 30 min prior to the addition of $\left[{ }^{3} \mathrm{H}\right]$ proline and the agonists (oxotremorine $(\mathrm{Oxo} ; 10 \mu \mathrm{M})$ or carbachol (Carb; at given concentrations)). Incorporation of $\left[{ }^{3} \mathrm{H}\right]$-proline into cellular proteins was expressed as percentage of the mean value of the respective controls of each individual cell preparation. Individual observations and mean values (horizontal bar) are shown. C: control. ${ }^{*}: p=0.54 ;{ }^{\bullet}: p=0.05 ;{ }^{+}: p=0.96$. ${ }^{* *}: p<0.01 ;{ }^{* * *}: p<0.001$.

(butaprost and forskolin) or to stimulate (TGF- $\beta_{1}$ ) collagen synthesis [20, 25] also showed corresponding effects in the present study.

In MRC-5 cells, carbachol as well as oxotremorine, two well known muscarinic receptor agonists, caused a clear increase in collagen synthesis. In contrast to oxotremorine, which is a pure muscarinic agonist, carbachol also has some nicotine receptor agonistic activity. However, $\leqslant 100 \mu \mathrm{M}$ nicotine did not significantly affect $\left[{ }^{3} \mathrm{H}\right]$-proline incorporation, which argues against a role of nicotine receptors in the effect of carbachol. Finally, interaction experiments, in which the effect of carbachol was antagonised by the long-acting muscarinic antagonist tiotropium (fig. 5), proved mediation via specific muscarinic receptors.

In previous experiments, it has been observed that the muscarinic receptors mediating proliferative effects in lung 
fibroblasts had pharmacological characteristics of $\mathrm{M}_{2}$ receptors and coupled to pertussis toxin sensitive G proteins [14]. Likewise, the muscarinic stimulation of collagen synthesis was also prevented by pertussis toxin (fig. 6) indicating the involvement of $G_{i / o}$ proteins in this effect. In the present study, a detailed pharmacological characterisation of the muscarinic receptors mediating stimulatory effects on collagen synthesis was not performed; however, of the five muscarinic receptor subtypes, only $\mathrm{M}_{2}$ and $\mathrm{M}_{4}$ receptors couple to pertussis-toxin sensitive proteins [26]. Moreover, MRC-5 cells express substantial amounts of transcript for $\mathrm{M}_{2}$ receptors, but only traces of mRNA encoding $M_{4}$ receptors (figs 1 and 2). Thus, $M_{2}$ receptors are also likely to mediate the muscarinic stimulation of collagen synthesis. Is this conclusion compatible with the high potency of tiotropium in antagonising the stimulatory effect of carbachol on collagen synthesis? Affinity constants of tiotropium are known for $\mathrm{M}_{1}, \mathrm{M}_{2}$ and $\mathrm{M}_{3}$ receptors and are similar for all three receptor subtypes $(0.1-0.3 \mathrm{nM})[27,28]$. However, the dissociation of the respective receptor complexes shows different kinetics, with the longest half-life for the tiotropium $-\mathrm{M}_{3}$ receptor complex $[27,28]$. This kinetic subtype selectivity of tiotropium may not be of significance in the present study because those experiments were performed under equilibrium conditions. However, whether the kinetic subtype selectivity of tiotropium is of clinical significance is still a matter of debate [29]. In any case, it is very likely that, under clinical conditions, tiotropium causes a significant blockade of $\mathrm{M}_{2}$ receptors in the lung, in addition to the blockade of $\mathrm{M}_{3}$ and $\mathrm{M}_{1}$ receptors, because the half-life of the tiotropium- $\mathrm{M}_{2}$ receptor complex, although shorter than that of the $\mathrm{M}_{3}$ and $\mathrm{M}_{1}$ receptors, is still quite long at $3.6 \mathrm{~h}$ compared with ipatropium, for which the dissociation half-life is in the range of 2-6 min for all three muscarinic receptors [27, 28].

Furthermore, in both MRC-5 cells and phLFbs, the muscarinic proliferative effects were mediated via activation of the extracellular signal-regulated kinase-mitogen-activated protein kinase pathway [15]. The present observations showed that PD 98059 prevented the carbachol-induced stimulation of $\left[{ }^{3} \mathrm{H}\right]$-proline incorporation indicating that this pathway is also essential for the muscarinic stimulation of collagen synthesis.

As mentioned previously, in HEL-299 and phLFbs, mRNA encoding $\mathrm{M}_{2}$ receptors is also the predominant muscarinic receptor transcript. In the present study, muscarinic agonists also stimulated collagen synthesis in these cells. Thus, as in previous studies investigating proliferative effects [14, 15], muscarinic receptor activation elicited the same response in phLFbs and human lung fibroblast cell lines.

In conclusion, the present results demonstrate muscarinic stimulation of collagen synthesis in cultured human lung fibroblasts. Together with previous observations showing muscarinic receptor-mediated proliferative effects [14, 15, 23], the current findings support the notion that cholinergic mechanisms could play a role in pro-fibrotic airway remodelling processes, which occur in chronic inflammatory and obstructive airway diseases. Inhibition of these processes, by prolonged blockade of airway muscarinic receptors, may contribute to the long-term beneficial effects of anticholinergics, as observed for the long-acting muscarinic antagonist tiotropium in chronic obstructive pulmonary disease.

\section{REFERENCES}

1 Jeffery PK. Remodeling and inflammation of bronchi in asthma and chronic obstructive pulmonary disease. Proc Am Thorac Soc 2004; 1: 176-183.

2 Molfino NA, Jeffery PK. Chronic obstructive pulmonary disease: histopathology, inflammation and potential therapies. Pulm Pharmacol Ther 2007; 20: 462-472.

3 Hogg JC, Chu F, Utokaparch S, et al. The nature of smallairway obstruction in chronic obstructive pulmonary disease. N Engl J Med 2004; 350: 2645-2653.

4 Barnes PJ. The role of anticholinergics in chronic obstructive pulmonary disease. Am J Med 2004; 20: Suppl. 17, 24S-32S.

5 Vincken W, van Noord JA, Greefhorst AP, et al. Improved health outcomes in patients with COPD during $1 \mathrm{yr}^{\prime} \mathrm{s}$ treatment with tiotropium. Eur Resp J 2002; 19: 209-216.

6 Anzueto A, Tashkin D, Menjoge S, Kesten S. One-year analysis of longitudinal changes in spirometry in patients with COPD receiving tiotropium. Pulm Pharmacol Ther 2005; 18: 75-81.

7 Racké K, Matthiesen S. The airway cholinergic system: physiology and pharmacology. Pulm Pharmacol Ther 2004; 17: 181-198.

8 Racké K, Juergens UR, Matthiesen S. Control by cholinergic mechanisms. Eur J Pharmacol 2006; 533: 57-68.

9 Krymskaya VP, Orsini MJ, Eszterhas AJ, et al. Mechanisms of proliferation synergy by receptor tyrosine kinase and $G$ protein-coupled receptor activation in human airway smooth muscle. J Respir Cell Mol Biol 2000; 23: 546-554.

10 Gosens R, Nelemans SA, Grootte Bromhaar MM, McKay S, Zaagsma J, Meurs H. Muscarinic M3-receptors mediate cholinergic synergism of mitogenesis in airway smooth muscle. J Respir Cell Mol Biol 2003; 28: 257-262.

11 Gosens R, Bos IS, Zaagsma J, Meurs H. Protective effects of tiotropium bromide in the progression of airway smooth muscle remodeling. Am J Respir Crit Care Med 2005; 171: 1096-1102.

12 Bos IS, Gosens R, Zuidhof AB, et al. Inhibition of allergeninduced airway remodelling by tiotropium and budesonide: a comparison. Eur Respir J 2007; 30: 653-661.

13 Jacobs JP, Jones CM, Baille JP. Characteristics of a human diploid cell designated MRC-5. Nature 1970; 227: 168-170.

14 Matthiesen S, Bahulayan A, Kempkens S, et al. Muscarinic receptors mediate stimulation of human lung fibroblast proliferation. Am J Respir Cell Mol Biol 2006; 35: 621-627.

15 Matthiesen S, Bahulayan A, Racké K. MAPK pathway mediates muscarinic receptor-induced human lung fibroblast proliferation. Life Sci 2007; 80: 2259-2262.

16 Peterkofsky B, Diegelmann R. Use of a mixture of proteinase-free collagenases for the specific assay of radioactive collagen in the presence of other proteins. Biochemistry 1997; 10: 988-994.

17 Schaeffer MR, Efron PA, Thornton FJ, Klingel K, Gross SS, Barbul A. Nitric oxide, an autocrine regulator of wound fibroblast synthetic function. J Immunol 1997; 158: 2375-2381.

18 Trevisan R, Yip J, Sarika L, Li LK, Viberti G. Enhanced collagen synthesis in cultured skin fibroblasts from insulindependent diabetic patients with nephropathy. J Am Soc Nephrol 1997; 8: 1133-1139.

19 Cairns JA, Walls AF. Mast cell tryptase stimulates the synthesis of type I collagen in human lung fibroblasts. J Clin Invest 1997; 99: 1313-1321. 
20 Goulet S, Bihl MP, Gambazzi F, Tamm M, Roth M. Opposite effect of corticosteroids and long-acting $\beta_{2^{-}}$ agonists on serum- and TGF- $\beta_{1}$-induced extracellular matrix deposition by primary human lung fibroblasts. J Cell Physiol 2007; 210: 167-176.

21 André C, Marullo S, Convents A, et al. A human embryonic lung fibroblast with a high density of muscarinic acetylcholine receptors. Eur J Biochem 1988; 171: 401-177.

22 Dudley DT, Pang L, Decker SJ, Bridges AJ, Saltiel AR. A synthetic inhibitor of the mitogen-activated protein kinase cascade. Proc Nat Acad Sci USA 1995; 92: 7686-7689.

23 Pieper MP, Chaudhary NI, Park JE. Acetylcholine-induced proliferation of fibroblasts and myofibroblasts in vitro is inhibited by tiotropium bromide. Life Sci 2007; 80: 2270-2273.

24 Bühling F, Lieder N, Kühlmann UC, Waldburg N, Welte T. Tiotropium suppresses acetylcholine-induced release of chemotactic mediators in vitro. Respir Med 2007; 101: 2386-2394.
25 Huang S, Wettlaufer SH, Hogaboam C, Aronoff DM, PetersGolden M. Prostaglandin E(2) inhibits collagen expression and proliferation in patient-derived normal lung fibroblasts via E prostanoid 2 receptor and cAMP signaling. Am J Physiol Lung Cell Mol Physiol 2007; 292: L405-L413.

26 Caulfield MP, Birdsall NJM. International Union of Pharmacology. XVII. Classification of muscarinic acetylcholine receptors. Pharmacol Rev 1998; 50: 279-290.

27 Disse B, Reichl R, Speck G, Traunecker W, Rominger KL, Hammer R. Ba 679 BR, a novel long-acting anticholinergic bronchodilator. Life Sci 1963; 52: 537-544.

28 Disse B, Speck GA, Rominger KL, Witek TJ Jr, Hammer R. Tiotropium (Spiriva ${ }^{\mathrm{TM}}$ ): mechanistical considerations and clinical profile in obstructive lung disease. Life Sci 1999; 64: 457-464.

29 Gosens R, Zaagsma J, Meurs H, Halayko AJ. Muscarinic receptor signalling in the pathophysiology of asthma and COPD. Respir Res 2006; 7: 73. 